\title{
The Steps to be Taken in Higher Education for Successful Adaptation to Industry $\mathbf{4 . 0}$
}

\author{
Endüstri 4.0’da Başarılı Olmak İçin Yükseköğretimde Atılması Gereken Adımlar \\ Nazlı Yüceol \\ Vocational School of Health Services, Istanbul Gelişim University, Istanbul, Turkey
}

\begin{abstract}
Özet
Toplumların ileri gitmesi, kalkınması, ekonomik anlamda rekabet edebilmesi, gelişmişlik düzeyleri ve daha birçok alt başlık eğitime bağlı olarak gerçekleşmektedir. Eğitim tüm bu alanlardaki değişimlerden hem etkilenmekte hem de tüm bu süreçleri etkilemektedir. Endüstri 4.0 olarak adlandırılan yeni dalga endüstri devriminden, istenilen sonuçların elde edilmesinin yolu ise yine eğitimden geçmektedir. Endüstri 4.0 ilk olarak Almanya'da ortaya çıkan ve otonom araçlar, giyilebilir teknolojiler yapay zekâ uygulamaları, blok zinciri, bulut bilişim sistemleri gibi uygulamaları içeren yeni sanayi devrimidir ve getirdiği yenilikler ile iş yapma şekillerini ve çalışanların sahip olması gereken yetkinlikler bağlamında değişiklikler yaratacaktır. Endüstri 4.0, sahip olunan vizyonun çok ötesinde üniversite öğrencilerinin mezun olduktan sonra hangi yeni bilgi, yetkinlik ve becerilere sahip olmaları gerektiğini, işgücünün kazanması gereken yeni becerilerin nasıl kazanılacağını ve tüm bunların sağlanabilmesi için yükseköğretimin yeniden yapılanmasını ve dönüşümünü gerektirmektedir. Bu bağlamda endüstri 4.0 eğitimin geleceğini yeniden şekillendirmektedir. Bu çalışma derleme türünde ele alınmıştr. Çalışmada ulusal ve uluslararası literatür incelenerek yükseköğretim ve endüstri 4.0 bağlantısı ortaya konmuştur. Bu bağlamda amacımız, endüstri 4.0'ın gerekliliklerine paralel olarak yükseköğretimde atılması gereken adımlar ve mezunlara kazandırılması gereken yeni yetkinler ile ilgili genel bir değerlendirme ortaya koymaktr. Yükseköğretimde öğretim programlarının mevcut süreçlere ve değişimlere uyum sağlaması, çağın koşul ve isteklerine uygun nitelikte insan gücünün yetiştirilebilmesi için uluslararası standartlarda neler yapılması gerektiği, işgücünün sahip olması gereken yeni yetkinliklerin ve süreç ile ilgili izlenmesi gereken adımların neler olduğu hakkında çıkarımlarda bulunulmuştur.
\end{abstract}

Anahtar sözcükler: Endüstri 4.0, sanayi devrimleri, yükseköğretim.

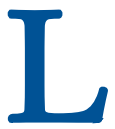
ooking at the history of humanity, one encounters revolutions, transformations and developments that have affected societies and social structures. Today, a new revolution is occurring and all societies will undergo radical changes in their structures and perspectives due to the advances in technology. These advances are transforming education systems, politics, social-cultural structure, and

\begin{abstract}
The progress of societies, their development, and their ability to compete economically depend on education. Education is both affected by changes in all these areas and affects them. The desired results from the new wave of industrial revolution called industry 4.0 can only be achieved through education as well. Industry 4.0 is the new industrial revolution that first appeared in Germany and includes applications such as autonomous vehicles, wearable technologies, artificial intelligence applications, block chain, and cloud computing systems. With the innovations brought by the revolution, it has been changing the ways of doing business and the competencies required from employees. Industry 4.0 requires university students to have new knowledge, competencies and skills before graduation, the workforce to acquire new skills, and the restructuring and transformation of higher education to achieve all of these. Thus, industry 4.0 is reshaping the future of education. This review study focuses on the connection of higher education and industry 4.0 by examining the national and international literature. It aims to present a general assessment of the steps to be taken in higher education in parallel with the requirements of industry 4.0 and the new competencies that should be acquired by graduates. It is concluded with some suggestions about what should be done regarding the international standards in order for the higher education curricula to adapt to the existing processes and changes, to train human resources in accordance with the conditions and demands of the age, what new competencies the workforce should have, and the steps to be followed regarding industry 4.0.
\end{abstract}

Keywords: Higher education, industrial revolutions, industry 4.0.

economies. It is in the best interest of society to analyze the requirements of the changes required and take the necessary steps to implement them. Focusing on education systems is needed to ensure that the inevitable changes that will occur are in the best interest of humanity. One of the most important problems that need to be resolved is how to facilitate the learning of this new industrial revolution at the university level.

\footnotetext{
İletişim / Correspondence:

Lecturer Nazlı Yüceol

Vocational School of Health Sciences, Istanbul Gelişim University,

Istanbul, Turkey

e-mail: nyuceol@gelisim.edu.tr
}

Yükseköğretim Dergisi / Journal of Higher Education (Turkey), 11(3), 563-577. @ 2021 Deomed Geliş tarihi / Received: Eylül / September 10, 2019; Kabul tarihi / Accepted: Şubat / February 6, 2021 Bu makalenin atıf künyesi / How to cite this article: Yüceol, N. (2021). The steps to be taken in higher education for successful adaptation to industry 4.0. Yükseköğretim Dergisi, 11(3), 563-577. doi:10.2399/yod.21.617715 
The fourth industrial revolution comprises digital technologies such as the internet of things, additive manufacturing and augmented reality (Calderón \& Izquierdo, 2020). Big data, internet of things, artificial intelligence, cloud computing, machine learning, augmented reality are the foundations of the industry 4.0 paradigm. This paradigm runs throughout industry 4.0 from transportation to energy production, agriculture to health, food to safety and education. Industry 4.0 forms the basis of the transition to digital communication used in all these areas (Assante, Caforio, Flamini, \& Romano, 2019).

Shortly after the announcement of industry 4.0 at the 2019 "Hannover Messe" fair in Germany, the concept of digitalization of production, which was part of the fourth industrial revolution, was highlighted at the World Economic Forum (WEF) in Davos in 2019. Extended discussions between education leaders and researchers focused on the development of higher education curriculum applied to industry 4.0 technology (Gleason, 2018). A transformation will occur in terms of professional dimensions, business dynamics, education systems, and working conditions (Liboni, Cezarino, Jabbour, Oliveira, \& Stefanelli, 2019). In parallel with these developments, industry 4.0 will require change in higher education. These discussions addressed how industry 4.0 will shape the future of education, what knowledge and skills students need from university-level training, and how the workforce will be able to accelerate new skill acquisition (Li, 2020). This included not only the characteristics of work, but also changes in job descriptions. Therefore, it is necessary to conduct studies on the changes needed in higher education and what steps should take place to achieve these.

Higher education institutions are transforming because of economic and socio-political changes, restructuring of government and university relations, globalization and marketization (Merrill, Finnegan, O’Neill, \& Revers, 2020). Looking at the mission of education, it is the responsibility of higher education to disseminate new knowledge, transfer learning to younger generations, provide the necessary updates while conducting this transfer and provide learners with the knowledge, skills and abilities that society needs to implement new knowledge (Özdemir, 2011), thus ensuring the integration of individuals with both their own society and the world. Industry 4.0 includes smart factories managed by cyber-physical systems where automated machines are at the forefront, robots and computers connected to each other via wireless technologies, and continuous technology development at an extremely high speed.

This transition of the traditional workforce results in reduced manufacturing and a creation of new jobs (Das,
Kleinke, \& Pistrui, 2020). These developments not only affect industrial productivity, but also change the labor market. With the development of digitalization and robotic technology, training potential employees for jobs that do not exist yet and developing technologies to solve problems that have not yet emerged are some of the inevitable consequences of industry 4.0. With industry 4.0, new competencies, knowledge and skills are emerging that university graduates must have. Higher education institutions should analyze these emerging competencies and develop a way to meet the business community's changing expectations for employee knowledge and expertise. Additionally, the individuals who receive higher education appropriate for the industry 4.0 change need to be flexible and capable of self-development (Abdullah, Humaidi, \& Shasrom, 2020).

Industry 4.0 has been the subject of considerable research due to its increasing importance. The purpose of this study is to reveal the structural changes necessary to enhance the relationship between industry 4.0 transformation and higher education in terms of new competencies graduates need and making recommendations for a framework to guide this transformation.

Karacan Özdemir and Ayaz (2020) have emphasized the importance of higher education coursework as a way to eliminate the gap in knowledge and competence in industry 4.0 studies. The findings of the study suggest the need to raise awareness about the subject through career services provided at the higher education level as well as to address the relevant infrastructural changes needed (Karacan Özdemir \& Ayaz, 2020). Jamaludin, McKay and Ledger (2019) stated in their study of the ASEAN region that real education reform will occur only when the changing needs of university graduates are in line with digital workforce competencies. The study urged revising the curriculum design to reflect the digital ecosystems of education 4.0 (Jamaludin et al., 2019). The University of the Future (2018) discussed the skills needed to succeed in the industry 4.0 environment based on 30 interviews with industry representatives and experts in the field. According to the findings obtained from the study, competencies that higher education institutions need to equip their graduates with are problem solving, critical thinking, soft skills, enhanced skills, communication, working cooperatively with others, and technological literacy (University of the Future, 2018). Lekha (2019) mentions that industry 4.0 will require profound changes in the content, presentation, pedagogy, structure and education management of educational services to provide appropriate training for the industry 4.0 workforce (Lekha, 2019).

In the current study, firstly, the historical development of the industrial revolution is explained. Section two presents the 
framework of the relationship between industry 4.0 and higher education. Section three outlines the steps higher education must take to meet the needs of industry 4.0. Section three also addresses the competencies required of graduates. The last section includes results and suggestions for future research related to the relationship between industry 4.0 and higher education.

\section{Historical Development of the Industrial Revolution and Industry $\mathbf{4 . 0}$}

Industrial revolutions have led to rapid and radical changes impacting the human experience (Blinder, 2006). Industrial breakthroughs that improve technology have led to increased production, enhanced efficiency, and contributed to social improvements. The fact that industrial revolutions strengthen economic development and provide competitive advantage necessitates close monitoring and adaptation. For this reason, step-by-step analysis of industrial revolutions measures their impact on individuals and societies (Kravchenko \& Kyzymenko, 2019).

The developments brought about by industrial revolutions occurred in four stages from the mid-18th to the early 21 st century (Bloem et al., 2014). Radical changes occurred in society due to industrial revolutions. The common feature of all four industrial revolutions is the support they received by both the business community and industry leaders (Firat Oktay, 2016). The first industrial revolution was industry 1.0 "machine age", the second industry 2.0 "electric age," the third industry 3.0 "electronic age," and the fourth is industry 4.0 "internet age" (Peters, 2017). Mechanical engineer James Watt's improvements in steam engine technology drove the industrial revolution. The first industrial revolution (industry 1.0) started in England around 1750 and continued until the 1840 s. The reason this period was the "machine age" is that the power of steam and water significantly increased productivity (Bahrin, Othman, Azli, \& Talib, 2016). The invention in question was the turning point in the history of mechanization by facilitating the transition from human and animal labor to machinery (Mohajan, 2019b). Using steam power, production capacity of the manufacturing industry increased. This played a critical role in the development of industries where steam engine was pivotal, especially coal mining (Agarwal \& Agarwal, 2017). This revolution, in which small businesses turned into large-scale businesses due to increase in production, was the beginning of an industrial culture that promoted quality and efficiency (Rojko, 2017).

The period between 1860 and 1914 witnessed the emergence of new inventions related to production and communication technologies. It was a second industrial revolution
(Mohajan, 2019b). The second industrial revolution was the electric age with an increased number of consumer products. Technological developments achieved in this period reduced the time and effort spent by the working class, offering greater efficiency for both business and home use. During this period, living standards and the purchasing power of consumers increased rapidly (Mokyr, 1999). The most striking innovation of the period was Henry Ford's first application of the conveyor system in the automobile factory in 1913 (Gen, Cheng, \& Lin, 2008). This development enabled efficiency, repeatability and high volume production. Another remarkable development of the electric age is the establishment of an electromagnetic system by Michael Faraday to prevent electrical fires in factories. This single factor improved working conditions significantly and eliminated the pollution caused by gas lighting (Agarwal \& Agarwal, 2017).

In the 1970s, with the introduction of computers and automation in industry, the third industrial revolution, called the "electronic age", started. The period decreased the need for a large workforce and increased production speed due to computer-assisted technologies. During this period electronic devices and information technologies showed a rapid rise. Computer systems played a key role in production processes, and this allowed for personal computers to become affordable. With the widespread use of digital tools and equipment for both design and production, manufacturers were able to create larger-scale mechanisms for production and offer them to consumers (Troxler, 2013). In the third industrial revolution, the shift from traditional fossil fuel use to renewable energy and technological innovations (such as the internet of things) where information technologies are the latest focus are gaining widespread attention (Lee et al., 2018). Continued developments in internet access, software, hardware, and telecommunications have resulted in technological advances that have transformed commercial applications, helping to achieve significant gains in productivity (Smith, 2001).

The transition from industry 1.0 to 2.0 took a century. There was half a century between industry 2.0 and 3.0, and the transition from industry 3.0 to 4.0 has been shorter ( Figure 1). Because this shortening between the transformations is due to the speed of technological change, the acceleration of technological developments will result in industry 4.0 being able to provide needed transitions in a much shorter time. High-level thinking skills such as efficient problem solving, as well as critical and creative thinking skills are the precipitants of industrial revolutions (Keleşoğlu \& Kalayc1, 2017, p. 70).

At a meeting in Germany in 2011, there was discussion of a fourth industrial revolution (industry 4.0). The working 


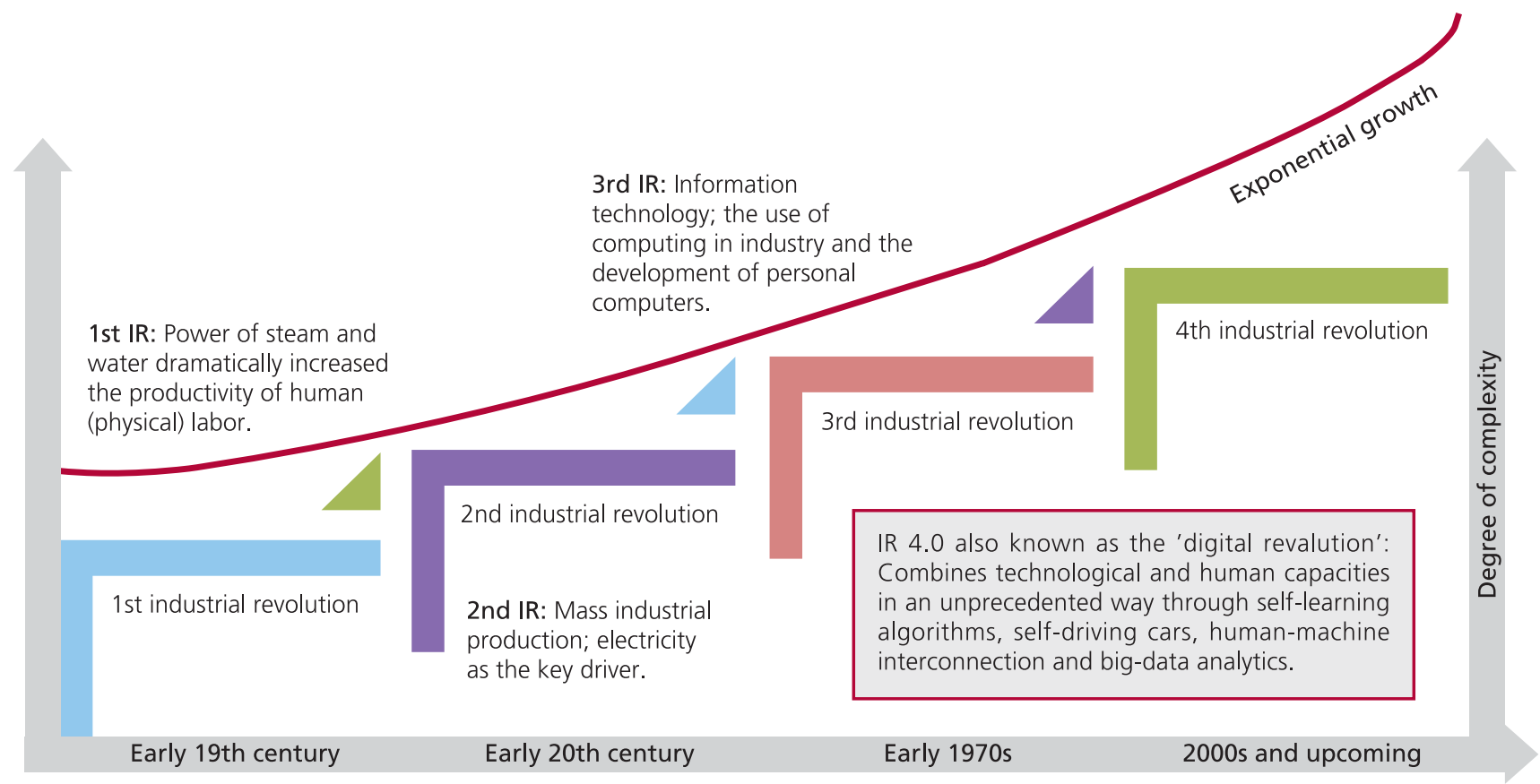

migure 1. History of industrial revolutions (Source: Haron, 2018).

group consisted of representatives from academia, industry, and government (Hermann, Pentek, \& Otto, 2016). Kagerman, Lukas ve Wahlster (2011) stated that the fourth industrial revolution includes not only the development in automation, but also smart observation and decision-making processes. Industry 4.0 is still a controversial term. On the one hand, it meets the criteria for a revolution. On the other hand, it is an evolutionary development rather than a sudden change and rupture (revolution) in industry (Alçın, 2016). The most important development leading to industry 4.0 is the use of the internet in industrial settings (Drath \& Horch, 2014). Basic technologies driving industry 4.0 are wearable devices, augmented reality, simulation, autonomous vehicles and robots, additive manufacturing, distributed ledger systems (such as blockchain), big data analytics, mobile computing, and cloud computing. These technologies have influenced the creation of new business models (University of the Future, 2018).

Human society has developed over time in line with production characteristics that have changed labor competencies and demands within economies. During the process, in parallel with industry 1.0-4.0 changes, society 1.0 , society 2.0 , society 3.0, society 4.0 and society 5.0 transformations have taken place. Society 1.0 was a hunter and gatherer society that start- ed 200,000 years ago and lasted until 10,000 years ago. Society 2.0 is an agricultural society that started 10,000 years ago and lasted until the 18th century. Agricultural civilizations established domesticity and families. Society 3.0 is an industrial society that started at the end of the 18th century and continued through the 20th century. In society 3.0, individuals enjoyed the fruits of the industrial revolution - mass production of consumer products. Society 4.0 is an information society that started in the late 20th century with the invention of the computer and has continued into the first part of the 21 st century society, and 5.0 is a "super smart" society that envisions solving social problems such as ending poverty by using technologies such as the internet of things and artificial intelligence (Kahraman, 2019).

One of the systems most affected by these changes in society is the education system. Changes have occurred in education systems during points of societal change. Education 1.0 was based on traditional methodologies of instruction where lecturing students was the norm (Jamaludin et al., 2019). This process is based on a one-sided flow of information from teacher to student. The teacher is authoritarian and the primary source of knowledge (Harkins, 2008). The instructor is active, and the student passively receives information. At the end of the process teachers evaluate students based on their 
ability to regurgitate the information presented. In traditional classroom environments lessons are lectures with textbooks used as the sole source for reinforcing them (Keats \& Schmidt, 2007). The use of technology was not part of the education 1.0 (Butt, Siddiqui, Soomro, \& Asad, 2020; Keats \& Schmidt, 2007).

Education 2.0, is a distance education model that includes strategies linked to internet use. This model provides for two-way communication between the teacher and the student and among the students themselves. This communication model can make the classroom environment less passive than education 1.0 (Puncreobutr, 2016). In this educational setting the use of technology for the display of videos and other content can be an integrated element.

Education 3.0 is a blended learning system that brings together face-to-face and distance education methods. In education 3.0, students function as resources for information to support the learning of other students (de Bittencourt, Goedert, Sharma, \& Bortolozzi, 2019). Students' responsibility is to create their own understanding of the knowledge addressed in the course rather than just memorizing information. In education 3.0, the role of the teacher has evolved from an authoritarian provider of information to a guide and coordinator who facilitates learning. Sources such as e-books and educational websites are learning tools. Collaboration, flexible scheduling, and creative use of content go beyond the traditional classroom environment and become available anywhere with internet access (Butt et al., 2020).

The competitive conditions in the business world have increasingly forced young people to adapt to new skills and competencies to be competitive in the rapidly changing society. However, educational settings rarely integrate technological developments such as $3 \mathrm{D}$ printing, multi-touch LCDs, cloud computing, virtual reality, holograms, augmented reality, biometrics, $\mathrm{AI}$ and $\mathrm{QR}$ codes to enhance learning. Innovation has become the new mantra of educational change (Halili, 2019). Peter Fisk (2017) defines education 4.0 as an education that can take place anywhere, anytime. Education 4.0 has a flexible structure and supports project-based learning that includes mentor support. Learning is under the control of the student and is shaped by self-assessments rather than multiple-choice examinations created by the teacher (Fisk, 2017).

Currently, people can direct simple machines with commands. With industry 4.0, machines will be able to manage themselves. Production will be more effective and flexible, producing smart products tailored to the specific preference of customers (Benešová \& Tupa, 2017). Industry 4.0 has also changed the production and consumption relations. Smart factories include smart machines and systems that perceive the business need through sensors, communicate via the internet and access production information to address consumer interests (Alçın, 2016). Industry 4.0 provides competitive advantages especially in high-tech fields (Man \& Strandhagen, 2017). Companies that cannot adapt to the new industrial revolution will eventually lose competitive edge. Industry 4.0 sparks international competition. The world is not only facing a challenge of sustainability but also facing technological advances such as digitalization and automation that will impact sustainability management (Man \& Strandhagen, 2017).

Industry 4.0 will have a significant impact on the manufacturing. This will lead to the creation of internet-based smart factories, smart products and smart services available on the industrial internet (Stock \& Seliger, 2016). Internet infrastructure constitutes the basis of industry 4.0. In the future people will no longer work in factories. The "dark factories" without employees do not need lights because there will be no human workers. At the same time, occupational safety risks will no longer exist since robots will replace people for jobs that involve elevated temperatures, heavy lifting, and toxic gases. A mobile phone module manufacturer in China modified its operation to become the first dark factory (Aksoy, 2017).

With the new industrial revolution, new jobs will emerge in parallel with the anticipated changes. Tax consulting, watch repairer, real estate brokering, food serving accountancy-auditing, industrial truck and tractor operator are the most suitable occupations for computerization. However, mechanical assembly, medical professions (especially surgical interventions), education management, primary and secondary school teaching, computer system analyst, anthropologists and archaeologists, forensic technicians are the professions least suitable for computerization (Frrat \& Firat, 2017).

Industry 4.0 has the power to affect business lines in every country with a rapid rate of change that will impact production, management, and control systems (Y1ldiz, 2017). Due to the changes resulting from industry 4.0 , the number of bluecollar jobs is gradually decreasing but a new white-collar class will emerge where creativity and leadership qualities are emphasized (Yazıcı \& Düzkaya, 2016). With the introduction of internet-based robots and automation systems, machines will be able to manage themselves. Thus, a new group of employees who are more innovative, creative and able to lead their team will emerge. For example, service sector growth is due to knowledge-based jobs. OECD countries employ more 
than one third of their working workforce in information activities (Gültan, 2003). Reich (1992) predicts that there will be three main groups of workers in the new economy. These will be symbolic analysts, routine producers, and personal servants. In the new economy, people who will receive the highest wages will be symbolic analysts. This will represent $25 \%$ of the work force. Creative workers will comprise about $20 \%$ of the workforce and about $30 \%$ of the workforce will be employed as personal servants. He predicted that the rest would be civil servants, farmers and miners, engineers, attorneys, and healthcare providers (Reich, 1992).

The number of workers doing routine work will gradually decrease as the number of machines and robots increases (Tonta \& Küçük, 2005). The 50th World Economic Forum held in 2020 identified the "Jobs of Tomorrow: Mapping Opportunity in the New Economy". In the seven main clusters listed within the report, there were ninety-six new professions and occupations. These new jobs represent 506 out of every ten thousand job opportunities in 2020, and 611 out of every ten thousand job opportunities by 2022. According to the report, new professions that will emerge include individuals with artificial intelligence expertise, medical transcriptionist, data scientist, customer success experts, and new fields of engineering. Occupations with the highest growth rate include social media assistant, waste biogas production system technician, wind turbine service technician, green marketing and growth hacker (individuals who design strategies to help businesses acquire and retain customers) (WEF, 2020). In parallel with all these developments, higher education must be prepared to bring the competencies required for these occupations to the academic setting.

\section{Industry 4.0 and Higher Education}

One area that will need to undergo radical changes due to the evolution of industry 4.0 is education. Changes in the job market and developments that occur in society impact education systems. It is also the case that education is an instrument for change in society. The education system is both affected by social developments influences social change. Higher education has a responsibility to equip its graduates with the skillset needed for adapting to a changing society. For this to occur, higher education must seek a place at the table when there are discussions about the competencies required for proficiency in skills needed to function effectively in an industry 4.0 world. If the world is currently in the information age, individuals who possess the skillset needed for the jobs of the information age will only be possible with an education system that addresses those skillsets. With globaliza- tion, one function of education is to facilitate individuals becoming producers rather than consumers (Özdemir, 2011). Providing training suitable for the future workforce is crucial and researchers anticipate that industry 4.0 will require profound changes in core aspects of education such as the content taught, mode of delivery, pedagogy, structure of training programs, and administrative services (Lekha, 2019).

With the new industrial revolution, it is necessary to make radical changes to higher education so that universities become pioneers of the digital age. Industry 4.0 and education 4.0 go hand in hand. Thus, education systems need a revolution to meet the changing labor force expectations of the future. At the 2018 Universities UK (UUK) conference, Joint Information Systems Committee (Jisc) introduced the education 4.0 concept and invited business, industry, and government leaders to work with universities to design and deliver technological solutions for a future-oriented student experience (THE, 2017). Within the concept of education 4.0, virtual and traditional classroom environments will merge. Higher education will be increasingly important as a training ground for the skills needed for industry 4.0. Under the higher education umbrella virtual learning environments should facilitate learning of the competency skills necessary to meet the demands of industry 4.0 (Benešová \& Tupa, 2017).

One concern about the technological advances in machine automation is that they will increase the unemployment rate. However, new professions will emerge, and the curricula to teach them must be adapted accordingly to address the types of training required for the new jobs (Flynn, Dance, \& Schaefer, 2017). For example, about $27 \%$ of the jobs in 2022 will be newly-defined job roles and $21 \%$ of the current jobs will disappear (WEF, 2018). According to the Employment Report of the Organization for Economic Development and Cooperation (OECD, 2019), 14\% of current occupations are under threat of extinction due to automation. The report also states that $32 \%$ of current workforce jobs will undergo significant skillset changes. To help decrease anxiety over job market insecurities, higher education institutions need to research the competency skills required for the new industry 4.0 careers and develop curriculum to include these skillsets. Updating the curriculum, supporting information technologies, innovation, entrepreneurship through R\&D activities within universities is essential to be able to keep up with the required competencies of the jobs created by industry 4.0 technology (Yazıcı \& Düzkaya, 2016).

Education has contributed to current levels of industrial evolution and technological progress. Universities have taken on the role of shaping the technology of the future by creating a test environment for innovation and educating future 
generations. Today, education can connect to mobile devices through applications in the "cloud" for both knowledge and skill acquisition. Thanks to technology, physical boundaries are no longer an obstacle to education due to national and global expansion of network services (Abu Mezied, 2016). Higher education institutions have a key role in empowering their students to shape their own futures by helping them to develop transferable skills and attitudes. These skills and attitudes are necessary to continually develop the core professional competences required for the jobs of the future (University of the Future, 2018). In industry 4.0, it is extremely important keep up with the pace of technology. It is necessary to make lifelong learning an integral part of one's career. The key to preparing individuals for the economy of the future is to offer quality education opportunities for everyone (US Government, 2016).

\section{Transformation Related to Industry 4.0 in Higher Education}

Universities have a significant role to play in the industrial revolution caused by digitalization. Due to industry 4.0 occupations will change or disappear, and new ones will emerge. These new professions will require new competencies. One area of great interest in higher education is innovation. For new professions that will emerge in the future in parallel with industry 4.0, universities should aim to create an information society with a focus on human excellence (Sharma \& Vij, 2020).

An industrial revolution is taking place while structural and functional changes are occurring in education systems. These changes necessitate competencies that individuals need to learn in a university setting. Determining the qualifications an individual needs to be successful in his/her career requires a job analysis. The planning of curriculum presentation of material and competency evaluation are important considerations. In guiding this process, one factor that helps the education system to fulfill the function of "meeting the need for qualified human resources" is the development and implementation of training programs (Demir, İlhan, \& Kalayc1, 2019). To address the challenges of industry 4.0, the following section will address the necessary transformations that higher education must initiate concerning new job skill competencies to meet the challenge of the industrial revolution.

\section{Steps Taken in the Transformation in Higher Education}

To be ready for industry 4.0, universities need to make structural and administrative changes with a strategic focus on required job skills needed for the new industrial revolution (Erdoğmuş, 2019). It is important for universities to be transparent and accountable to the community. Structures that ensure transparency and accountability help to fulfill institutional responsibilities to stakeholders (Erdoğmuş, 2019). Because it is extremely important that higher education institutions cooperate with their stakeholders regarding industry 4.0 , cooperation needs oversight. In the process of restructuring higher education, universities should consider non-centralized structures that allow for more institutional autonomy but with oversight to ensure continued stakeholder support.

The changes in the business and occupational markets that result from industry 4.0 need to be a top priority for universities. Universities must be prepared to create departments and programs in line with job skill requirements and stakeholder expectations. To accommodate the new professions that will emerge from industry 4.0, current departments and programs at universities will have to revamp their curriculum accordingly. For example, Hamburg University Nanotechnology Department in Germany have professors who have won six Nobel Prizes in research and development. The Department of Neuromotor Sciences at Bologna University is one of the leading research departments in Italy. Biomolecular Engineering Department at Darmstadt Technical University, which founded IT-Cluster Rhine-Main-Neckar, is also known as "Silicon Valley of Germany. ${ }^{[1]}$ In addition, an Artificial Intelligence Engineering Department has been opened at Istanbul Technical University in Turkey. ${ }^{[2]}$

An important aspect of industry 4.0 is lifelong learning. Lifelong learning refers to an on-going initiative-taking search for knowledge throughout one's life for personal or professional reasons. It encompasses enhanced active citizenship and interest in personal development. It can ensure self-sustainability, innovative competitiveness, and enhanced employability. ${ }^{[3]}$ Higher education institutions face a strategic imperative to expand access to lifelong learning opportunities that make education more widely accessible to diverse student populations. Given the movement toward greater globalization of industries, demographic changes that have prompted migration and the rapid pace of technological progress, promoting lifelong learn-

[1] Retrieved on 13.10.2020 from https://www.draftegitim.com/blog-icerik/yeni-dunya-duzeni-yeni-meslekler/1093

[2] Turkey's first Artificial Intelligence and Data Engineering Department at Istanbul Technical University is in the Faculty of Computer and Informatics. The department, which accepted its first students in 2020-2021, carries the national and international artificial intelligence and data engineering studies conducted within ITU to undergraduate education. Retrieved on 23.10.2020 from https://yapayzeka.itu.edu.tr/

[3] Retrieved on 13.10.2020 from https://en.wikipedia.org/wiki/Lifelong_learning 
ing opportunities and strategies in higher education settings has become extremely important (Yang, Schneller, \& Roche, 2015). With its cadre of academic expertise, training mandate, broad knowledge-base and drive for innovation for innovation, the higher education sector has enormous potential for promoting and implementing a pedagogy for lifelong learning (Guerra, 2020).

Society is rapidly changing due to environmental, scientific, and technological transformations. The impact of globalization on all aspects of life is enormous including culture and education. Coping with these changes and shaping the future accordingly requires creative and innovative policies. Promoting lifelong learning as a tool for enhancing quality of life is a goal that supports a sustainable future. To meet this challenge, it is important for higher education institutions to play a pivotal role in supporting life-long learning (UNESCO, 2020). The report prepared by the UNESCO Lifelong Learning Institute includes findings from studies in different countries about how to strengthen individual drive for lifelong learning. The report argues that there should be a separate unit at universities for lifelong learning. Community organizers, social change activists, academic staff, and representatives from the university senior management should be involved in creating these learning spaces and support should come from institutions such as UNESCO. In the same report, in the section related to higher education institutions in China and Denmark, there are findings that a common understanding of lifelong learning should be encouraged by the university and its stakeholders and the integration of lifelong learning perspective in institutional policies and practices should be ensured. Higher education institutions should adopt a mission statement that includes "transforming into a lifelong learning institution". This should apply to the operation plans for each department of the university (Yang, Schneller, \& Roche, 2015).

Universities should create social and economic value by establishing close cooperation and partnerships with businesses in research and education (Erdoğmuş, 2019). Developing a plan for cooperation between relevant stakeholders should be among the priority steps to accelerate innovative practices to address the needs of the fourth industrial revolution (University of the Future, 2018). It is extremely important that higher education institutions cooperate with the relevant parties to manage the process of addressing workforce demands. External stakeholders of universities may include other higher education institutions, non-governmental organizations, public institutions, private sector organizations, employers, professional associations, and industry unions. An international strategic institutional partnership coordinated with European Universities and the European University Association published a study about business and higher education cooperation. More than 800 member universities in 48 European countries and thirty-three national university associations participated in the research. According to the results, higher education institutions collaborate with various partners in different contexts for different purposes. While cooperation occurs between institutions with similar profiles, the cooperation of institutions with different but complementary profiles also stood out in the study. Cooperation with the business, community and industry as well as non-governmental organizations, governmental ministries and public institutions is important. Universities work in diverse ways with partners around the world. All institutions in the sample had partnership with entities outside of Europe, making them truly global actors. These universities had strategic cooperation agreements with their partners abroad (Claeys-Kulik et al., 2020).

Universities must take action to individualize the learning experience of their students more fully. Ideally, students should have their own learning management systems and determine their own learning paths in accordance with the competencies required for their chosen field of study. With industry 4.0, individuals will need an elevated level of communication skills. Lifelong learning should support students in achieving their personal and academic goals (Fisk, 2017). The opportunities offered by digital technologies, individualized learning modules, open content and the new technologyoriented global world are available now (Demir, İlhan, \& Kalayc1, 2019). As an alternative to standardizing educational practices, student-centered learning experiences are of paramount importance. For this, it is necessary to adopt data mining to better understand student performance and to offer programs designed to meet the demands of the marketplace while considering the needs of each individual student. Data on student performance, behavior, development and interaction in classrooms and on the online platforms of massive open online courses (MOOCs) ${ }^{[4]}$ as well as data from smart campus can create learning modules for diverse learners. The ability of higher education institutions to integrate this information into smart data will result in smart decisions for providing customized education and personalized learning experience for students (Abu Mezied, 2016).

[4] Mass Open Online Courses (MOOCs) are free online courses that anyone can enroll in. MOOCs provide a cost-effective and flexible way to learn new skills, advance career and provide quality educational experiences on a large scale. Retrieved on 12.10 .2020 from https://www.mooc.org/ 
The primary skills required for jobs in industry 4.0 are technology-related skills. In 2018, the International Computer and Information Literacy Survey (ICILS) organized by the European Commission with the participation of fourteen countries ${ }^{[s]}$ sought an answer to the following question: "How well are students prepared for education, work and life in a digital world?" The survey conducted with the participation of 46,000 students worldwide revealed that only $2 \%$ of the students were able to demonstrate the ability to critically evaluate the information found online.

Research results suggest that providing students with information and communication technology (ICT) equipment alone does not automatically lead to the development of digital literacy skills. Students need to understand how to use computers effectively and the instructors who provide this training should be given ICT support (Fraillon, Ainley, Schulz, Friedman, \& Duckworth, 2018). Higher education institutions should not only provide technological equipment for technology literacy. Students must also have the critical thinking skills necessary to analyze the data that is readily available to them when surfing the web. The responsibility of educational institutions includes not only teaching the use of technology but also the critical thinking skills necessary for accurate interpretation of data.

Education systems that include active use of technology are becoming increasingly common. There is a widespread use of blended learning systems where instructors use PowerPoint presentations to provide audio-visual support for the classroom learning experience. Digitizing education brings benefits. One of them is that students can access the course content from home through a learning management system (LMS) that is available to them 24/7. This supports greater opportunity for transfer of information from working memory to long-term memory (Etgigrup, 2020). Blended learning and virtual environments (eg video conferences) offer educational value in the process of knowledge transfer and active engagement, for real-time experiences or asynchronous engagements (eg forums and chats). Higher education systems need to look at how they can adopt greater use of technology, transforming the learning environment for optimal benefit of the student (Xing \& Marwala, 2017).

Higher education institutions should undertake the tasks of offering career development and consultant services to bring the innovations that result from industry 4.0 into programs for lifelong learning. For example, the Virtual Learning and Teaching Factory for Industry 4.0, created under the International Joint Post-graduation in industry 4.0 - Digital Innovation and Transformation Project is a free and open platform to the public. Courses appear as small learning modules where participants can learn course content and watch video lectures at their own pace. Sample course titles are Basics of Additive Manufacturing, Basics of Prototyping, Data Analytics 101: What You Need to Know for Data Analytic Thinking. This is a platform where project resources are available with multiple tools. After completing a course, participants share their feedback by filling out a short questionnaire. The main purpose is to encourage direct contact of target groups with the main components of industry/education 4.0, as well as to encourage exchange of experience and discussion on current and emerging issues (University of the Future, 2020).

\section{New Competencies to be Acquired by Graduates in Higher Education}

Industry 4.0 will transform the workforce. Higher education institutions must first determine these new skills and competencies needed and how best to teach these skills and competencies. One task of the university will be help students make informed decisions about usability, sustainability, safety, and ethics while working with artificial intelligence, robotics, and cyber-physical systems.

Human interaction is an inevitable aspect of modern society. Therefore, communication skills are important for the workplace. Workers now connect with each other more than ever. While digitalization, robotization, artificial intelligence and the industrial internet increase the degree of immaterial labor, jobs of the future will emphasis the importance of teamwork and critical thinking while sharing ideas with others. The 21 st century core competencies come from diverse sources. Developed by the US Department of Education, businesses such as Apple, AOL, Microsoft, Cisco, and SAP, as well as a coalition of educationrelated organizations such as the National Education Association, identified a model that incorporates 21st century skills into learning activities (Battelle for Kids, 2019). The P21 framework created in relation to 21 st century competencies shows that critical thinking, communication, collaboration, and creativity are important skills for all students to learn. The goal is for every child, without exception, to experience 21 st century learning ${ }^{[6]}$ of these four skills.

These same competencies expressed earlier as learning and innovation skills are in the OECD 2008 report. The competen-

[5] France, Portugal, United Kingdom, Chile, Uruguay, Italy, Moscow, Kazakhstan, Korea, Germany, Finland, Denmark, Luxembourg, North Rhine-Westphalia

[6] Retrieved on 16.10.2020 from https://www.battelleforkids.org/networks/p21 
cies list from 2008 includes critical thinking and problem solving, creativity and innovation, communication and cooperation, information and media literacy, ICT literacy, life and career skills, flexibility and adaptability, initiative and self-management, social and cross-cultural skills, productivity and accountability, leadership and responsibility (OECD, 2008).

Critical thinking skills are extremely important in working life (Hillage \& Pollard, 1998). Critical thinking skills include scientific literacy which helps to critically understand the world around us and to categorize copious amounts of information. Scientific literacy is necessary not only to understand and use advancing technology, but also as a tool for solving problems. Problem solving, as a facilitating factor for the thinking process, includes the processes of observing, defining, and formulating creative thought (Passow \& Passow, 2017).

Critical thinking in the business environment is a skill that raises questions and analyzes problems with a solution-oriented approach that enables more efficient problem-solving. College students can develop the skills of critical thinking, questioning, understanding events, interpreting, and producing solutions as key skills for industry 4.0. To gain critical thinking competency, Critical Thinking Lesson Plans prepared by TED-Ed, Critical Thinking Resources by Resilient Educator, Believing Game and Doubtful Game models offered by Morningside Center ${ }^{[7]}$ can be adapted to college level training. For example, Believing Game and Doubtful Game enables students to question opinions, ask appropriate problem-solving questions, create opposing points of view and follow a critical thinking perspective (Stauffer, 2020).

Soft skills will also be needed for the industry 4.0 environment. Soft skills are the personal attributes that enable a person to interact with other people effectively and harmoniously. Interpersonal skills are an important part of professional life. Soft skills allow people to work together, collaborate and learn from each other. These attributes include written communication, verbal communication, negotiation skill, persuasion, and presentation skills, as well as teamwork, leadership, networking, and social skills (McQuaid \& Lindsay, 2005). Collaboration refers to working together and solving a problem together to get the best possible results. Collaboration may at times seem difficult, but it can enhance decision-making and problem solving. The key element of collaboration is willingness to collaborate. All participants must be willing to problem-solve as a team to achieve an agreed-upon goal (Stauffer, 2020). This means understanding the idea of "always better" and this will always take businesses and employees a step further. Applications such as ThoughtCo, PE Central, A to Z Teacher Stuff give students opportunities to practise collaboration. For example, within the scope of ThoughtCo's lesson based on a puzzle method, each student in a group conducts research on a small part of a broad topic first. Then, each student teaches the other group members his/her part of the topic. After that, students move from their original groups and talk to other students who specialize in the same field, exchanging information and giving feedback (Stauffer, 2020). In this activity, participants learn both cooperation within their own teams and cooperation between groups.

Technological literacy is one of the most important skills to learn. Technological literacy in its simplest form is familiarity with or knowledge of modern engineering tools (Passow \& Passow, 2017). In a broader definition, it is having the language necessary to talk about technology. Therefore, it is necessary to talk about two aspects of technological literacy, the first is related to equipment, i.e., technology tools, and the other is related to the acquired knowledge. Knowledge refers to knowledge about the physical properties of the work, its functions, or the relationship between the two, i.e. how physical properties affect the function (Dakers, 2006). Technological literacy is being able to use a piece of technology correctly and have a critical perspective of how to use the information gained from it. The future workforce needs to have an awareness of technology applications and their impacts. This includes basic understanding of data management with the ethical and legal issues that come with it. Value creation, as well as managing internal and external information needs, is extremely important. As network economies become more prevalent, the role of information and data management will become crucial. Also, empathy with the user is an essential element in creating successful technological solutions. Leadership, communication and interpersonal skills to engage people, align strategic goals, and acquire resources for technological investments will be key adaptation skill. However, these efforts must include evaluating the ethical implications for the development and use of innovative technologies (University of the Future, 2018). From this point of view, studies on professional skills emphasize the importance of a wide variety of information to understand the impact of decisions made in a field in different areas (University of the Future, 2018). By addressing the issue of social innovation in the context of industry 4.0, Morrar, Arman and Mousa (2017) acknowledge the importance of understanding the impact of technology on society. Before making decisions, the issues [7] The Morningside Center is a community-focused, nonprofit organization that is set up to create compassionate, productive, and equitable schools where students learn the skills they need
to contribute to their communities, from the classroom to the world, striving to increase ethnic equality in schools while developing social and emotional skills. Retrieved on 16.10 .2020 from https://www.morningsidecenter.org/about. 
involved need the perspective of different stakeholders, if there are problems, it is necessary to address them prior to making a final decision.

One of the most important issues in preparing for industry 4.0 is to bring in well-qualified employees capable of coping with the increasing complexity of production systems. One skill needed is finding creative and practical solutions for complex problems, which requires developing digital skills and creating technology education programs. As automation and cyber-physical systems become the norm, the future workforce needs to be ready to take initiative and make decisions. Interdisciplinary knowledge is extremely important to develop creative solutions to complex problems (Adolph, Tisch, \& Metternich, 2014). The vertical and horizontal digital integration of production processes means automation of communication and collaboration throughout standard processes. Accordingly, employees will need the ability to understand the relationships between processes, information flows, potential failures and solutions. Increasing scope and complexity requires a mindset of creating and maintaining networks of experts to be able to temporarily collaborate to find appropriate solutions to specific problems. Employees will have to focus on processes where human flexibility is advantageous, such as problem solving and creativity. Creative activities here will take place in a dispersed social environment, involve different cross-community teams, and will also require the ability to communicate complex problems (Erol, Jager, Hold, Ott, \& Sihn, 2016). For example, across the United States, technology is now shaping the way students interact with content, develop communication and creativity skills (Dousay \& Weible, 2019). Stork (2019) reached the conclusion that digital storytelling techniques are useful for achieving 21st century competencies. In a study with sixteen students at a three-week summer camp, Sphero Bot designed and created an interactive story using robots as characters. The study concluded that this digital storytelling method enhances critical thinking, technology literacy, and creative thinking skills that are part of the 21 st century competencies needed by the workforce (Stork, 2020).

Similar results were published in a report by the World Economic Forum (2016) on the workforce skills that industry 4.0 requires. According to the report, the skills needed for the industry 4.0 workforce are a strong service orientation, emotional intelligence, negotiation, cooperation, persuasive communication ability, critical thinking, decision-making, and cognitive flexibility (WEF, 2016). The European Parliament and Council of the EU (2006) have identified eight critical competencies for industry 4.0. The competencies must be attainable in both the first language and subsequent learned languages spoken by an individual. These are communication, mathematics and basic sciences and technology competencies, digital competencies, learning to learn skills, social and civic competencies, a sense of initiative and entrepreneurship and cultural sensitivity. The link between industry 4.0 , society 5.0 , and education 5.0 is undeniable. Education is undoubtedly has a close relationship with the issues related to society 5.0 due to its significant impact on social change. Considering the topics of quality education, healthy work environments, economic growth, industry, and innovation within the scope of the United Nations' 17 sustainable development goals, the relationship between industry 4.0 and higher education will continue to grow.

\section{Conclusion and Recommendations}

Basic technologies used by industry 4.0 such as wearable devices, augmented reality, simulation, autonomous vehicles and robots, additive manufacturing, distributed ledger systems (such as blockchain), big data analytics, mobile computing, and cloud computing are most probably here to stay. New business models will come from with these technologies (University of the Future, 2018). Peter Drucker's statement "The next society will be an information society where knowledge will be the source and knowledge workers will be the dominant workforce" points to the new society and new workforce that will emerge with industry 4.0 (Singh, 2020). Undoubtedly, one of the most important actors in this transformation process will be higher education since it serves as the training ground for an educated workforce. Industry 4.0 has progressed faster than other industrial revolutions due to the exponential development of technology. Advances in technology require technology skills that are flexible because the world is diverse and yet interconnected. Industry 4.0 will have an inevitable impact on the higher education sector (Lekha, 2019). Universities of the future need to focus on enhancing their connections to industry and societyrelated research and development. Higher education will be an important support system for local and global industrial growth (Sharma \& Vij, 2020). Future professionals must be flexible and ready to learn from people with diverse backgrounds and experiences in new environments. Industry 4.0 will require technologically-literate human resources (Lekha, 2019). The President of the World Economic Forum, Klaus Schwab said, "We are on the verge of a technological revolution that will fundamentally change the way we live, work and relate to each other. Transformation is unlike anything humanity has ever experienced before in terms of scale, scope and complexity" (Lekha, 2019). For these reasons, higher education institutions need to closely follow the innovations resulting from industry 4.0 , and they need to transform to adapt to the expectations by industry 4.0. 
Considering the need for change in the education system, employers must cooperate with schools and universities to ensure the availability of a well-trained workforce. Therefore, education systems must be able to access market information to create curricula for training programs relevant to industry 4.0. There is also the need to adapt education systems to support lifelong learning initiatives. In parallel with technological, economic and social changes, education and labor policies need to be re-examined and transformed to make them more initiativetaking for adaptation to rapidly changing market realities (Lodder, 2016). Higher education systems must adopt the teaching method for the benefit of all and transform the learning environment. In addition, they should understand the requirements of the age in the most accurate way by conducting continuous development studies that address the needs of industry 4.0. During this fourth industrial revolution, a new type of university that provides learning opportunities and research services to a diverse population with unique needs is emerging. This new university is increasingly interdisciplinary, has virtual classrooms and laboratories, virtual libraries and teachers, and strives to continuously improve teaching modalities that will enhance the education experience (Xing \& Marwala, 2017).

The top priority areas that need transformation in the education system are free access, individualized education, mental transformation, integration of digital technologies into educational setting, uninterrupted learning environments, lifelong learning, discovery education, and interdisciplinary learning. Graduates are expected to have enhanced communication skills, technological skills, and learning-tolearn skills (Himmetoğlu, Ayduğ, \& Bayrak, 2020). 21st century core competencies are analytical thinking and innovation, active learning and learning strategies, creativity, originality and taking initiative, technological literacy and programming critical thinking and analyzing, problem solving, leadership collaboration, systems analysis and evaluation. These are the critical competencies for the workforce of the future (Erdoğmuş, 2019). The function of higher education is being re-examined and must adapt to the reality of industry 4.0 (Yildiz, 2017). In today's rapidly digitalizing world, there is no option to bypass this reality. Universities, businesses, and governments must adapt to the new revolution. Higher education must take initiative in this endeavor.

Education must reorganize so individuals can access learning from wherever they are and in a format most useful to their needs. Universities must provide an education that supports the learning of industry 4.0 technology. By creating classrooms, laboratories, and virtual environments that sup- port active learning, it is possible to improve the learning outcomes for all students (Lekha, 2019).

Industry 4.0 needs a $5 \%$ increase in trained workforce. This is based on a $2-3 \%$ economic growth every year, which requires an adequate supply of well-qualified college graduates who can adapt to the workforce requirements of industry 4.0 (Yazıc1 \& Düzkaya, 2016). It is extremely important for higher education institutions to provide the necessary training for graduates to have technology literacy, critical thinking skills, collaboration ability, creativity, critical thinking skills, and interest in lifelong learning. To raise individuals who question processes, enjoy learning to learn, have training in the use of technical infrastructure and equipment, know how to conduct research, can interpret the information obtained, have high emotional intelligence, are creative, have cognitive flexibility, are equipped with critical thinking skills, have efficient problem solving skills, and have a designer mindset will be necessary for success in the industry 4.0 world.

Future studies on this subject should have a wider scope by considering society 5.0 and education 5.0 with a futuristic approach. Undoubtedly, because of its impact on society, education is closely related to society 5.0. Studying this subject in connection with sustainability issues would be a remarkable contribution to the literature. An integrative research focus on the topics of quality education, work satisfaction, economic growth, industry and innovation referring to the United Nations 17 sustainable development goals would be another valuable contribution to the literature since they are closely connected to industry 4.0 and education.

Araştırma Fonu Desteği / Funding: Bu çalışma herhangi bir resmi, ticari ya da kar amacı gütmeyen organizasyondan araştırma fonu desteği almamışur. / This research did not receive any specific grant from funding agencies in the public, commercial, or not-for-profit sectors.

Etik Standartlara Uygunluk / Compliance with Ethical Standards: Yazar bu makalede araştırma ve yayın etiğine bağlı kalındığını, Kişisel Verilerin Korunması Kanunu'na ve fikir ve sanat eserleri için geçerli telif hakları düzenlemelerine uyulduğunu ve herhangi bir çıkar çakışması bulunmadığını belirtmiştir. / The author stated that the standards regarding research and publication etbics, the Personal Data Protection Law and the copyright regulations applicable to intellectual and artistic works are complied with and there is no conflict of interest.

\section{References}

Abdullah, Q. A, Humaidi, N., \& Shasrom, M. (2020). Industry revolution 4.0: The readiness of graduates of higher education institutions for fulfilling job demands. Romanian fournal of Information Technology and Automatic Control, 30(2), 15-26.

Abu Mezied, A. (2016, January 22). What role will education play in the Fourth Industrial Revolution? World Economic Forum. Retrieved from https://www.weforum.org/agenda/2016/01/what-role-will-educationplay-in-the-fourth-industrial-revolution/ (November 10, 2020). 
Adolph, S., Tisch, M., \& Metternich, J. (2014). Challenges and approaches to competency development for future production. Fournal of International Scientific Publications, 12, 1001-1010.

Agarwal, H., \& Agarwal, R. (2017). First industrial revolution and second industrial revolution: Technological differences and the differences in banking and financing of the firms. Saudi Fournal of Humanities and Social Sciences, 2(11), 1062-1066.

Aksoy, S. (2017). Değişen teknolojiler ve endüstri 4.0: Endüstri 4.0'1 anlamaya dair bir giriş. SAV Katkı, 4, 34-44.

Alçın, S. (2016). A new theme for production: Industry 4.0. [Article in Turkish] Fournal of Life Economics, 3(2), 19-30.

Assante, D., Caforio, A., Flamini, M., \& Romano, E. (2019). Smart education in the context of industry 4.0. 2019 IEEE Global Engineering Education Conference (EDUCON) (pp. 1140-1145), April 8-11, 2019, Dubai, UAE.

Bahrin, M., Othman, M., Azli, N., \& Talib, M. (2016). Industry 4.0: A review on industrial. Furnal Teknologi, 78(6-13), 137-143.

Battelle for Kids (2019). Frameworks \& resources. Retrieved from battelleforkids.org/networks/p21/frameworks-resources (October 16, 2020).

Benešová, A., \& Tupa, J. (2017). Requirements for education and qualification of people in industry 4.0. Procedia Manufacturing, 11, 2195-2202.

Blinder, A. S. (2006). Offshoring: The next industrial revolution? Foreign Affairs, 85(2), 113-128.

Bloem, J., Doorn, M. V., Duivestein, S., Excoffier, D., Maas, R., \& Ommeren, E. V. (2014). The fourth industrial revolution - Things to tighten the link between IT and OT. Groningen: Sogeti VINT Research Report 3. Retrieved from https://www.sogeti.com/globalassets/global/special/ sogeti-things3en.pdf (October 17, 2020).

Butt, R., Siddiqui, H., Soomro, R. A., \& Asad, M. M. (2020). Integration of industrial revolution 4.0 and IOTs in academia: A state-of-the-art review on the concept of education 4.0 in Pakistan. Interactive Technology and Smart Education, 17(4), 337-354.

Calderón, R. R., \& Izquierdo, R. B. (2020). Machines for Industry 4.0 in higher education. In 2020 IEEE World Conference on Engineering Education (EDUNINE2020) (pp. 1-4), March 15-18, 2020, Bogota, Colombia.

Claeys-Kulik, A.-L., Jørgensen, T. E., Stöber, H., Pruvot, E. B., Gaebel , M., Loukkola, T., ... Mezher, I. (2020). International Partnerships \& the European Universities Initiatives. European University Assosation. Retrieved from https://eua.eu/downloads/publications/eua\%20international\%20partnerships\%20survey.pdf (October 17, 2020).

Dakers, J. R. (2006). Defining technological literacy. Towards an epistemological framework. New York, NY: Palgrave Macmillan.

Das, S., Kleinke, D. K., \& Pistrui, D. (2020). Reimagining engineering education: Does industry 4.0 need education 4.0? 2020 ASEE Virtual Annual Conference Experience (pp. 1-20), June 22-26, 2020, Virtual Online.

de Bittencourt, D. F., Goedert, A. R., Sharma, R. C., \& Bortolozzi, F. (2019). Framework blockchain education: Rupture in higher education. In R. C. Sharma, H. Yildırım, \& G. Kurubacak (Eds.), Blockchain technology applications in education (pp. 80-96). Hershey, PA: IGI Global.

Demir, F., İlhan, E., \& Kalaycı, N. (2019). Curriculum 4.0: One of the Means of achieving the targeted transformation in higher education. [Article in Turkish] Bayburt Eğitim Fakiiltesi Dergisi, 14(28), 432-466.

Dousay, T. A., \& Weible, J. L. (2019). Build-a-bug workshop: Designing a learning experience with emerging technology to Foster creativity. TechTrends, 63(1), 41-52.
Drath, R., \& Horch, A. (2014). Industrie 4.0: Hit or hype? IEEE Industrial Electronics Magazine, 8(2), 56-58.

Erdoğmuş, N. (2019). Geleceğin Tïrkiye'sinde yiikseköğretim. İstanbul. Retrieved from https://ilke.org.tr/images/pdf/y\%C3\%BCksekogretimsunum-son.pdf (October 10, 2020).

Erol, S., Jager, A., Hold, P., Ott, K., \& Sihn, W. (2016). Tangible industry 4.0: A scenario based approach to learning for the future of production. Procedia CIRP, 54, 13-18.

Etgigrup (2020). Blended learning nedir? Retrieved from https://etgigrup.com/blended-learning-nedir/ (October 12, 2020).

European Parliament (2006). Recommendation of the European Parliament and of the Council. European Parliament. Retrieved from https://eurlex.europa.eu/LexUriServ/LexUriServ.do?uri=OJ:L:2006:394:0010:00 18:en:PDF (October 16, 2020).

Fırat Oktay, S. Ü. (2016). Sanayi 4.0 dönüşümü nedir? Belirlemeler ve beklentiler. Global Sanayici Dergisi, 1-10. Retrieved from http://www.sanayicidergisi.com.tr/sanayi-40-donusumu-nedir-belirlemeler-ve-beklentiler-makale,585.html (October 17, 2020).

Fırat, S. Ü., \& Fırat, O. Z. (2017). Sanayi 4.0 devrimi üzerine karşılaştırmalı bir inceleme: Kavramlar, küresel gelişmeler ve Türkiye. Toprak İ̧veren Dergisi, 114, 10-23.

Fisk, P. (2017). Education 4.0: The future of learning will be dramatically different, in school and throughout life. Retrieved from https://www.peterfisk.com/2017/01/future-education-young-everyone-taught-together/ (October 12, 2020).

Flynn, J., Dance, S., \& Schaefer, D. (2017). industry 4.0 and its potential impact on employment demographics in the UK. In J. Gao, M. E. Souri, \& S. Keates (Eds.), Advences in manufacturing technology XXXI (pp. 239-244). Amsterdam: IOS Press.

Fraillon, J., Ainley, J., Schulz, W., Friedman, T., \& Duckworth, D. (2018). IEA International Computer and Information Literacy Study 2018 International Report. The International Association for the Evaluation of Educational Achievement. Retrieved from https://www.iea.nl/sites/default/files/2020-04/IEA\%20International\%20Computer\%20and\%20Information \%20Literacy\%20Study\%202018\%20International\%20Report.pdf (October 17, 2020).

Gen, M., Cheng, R., \& Lin, L. (2008). Network models and optimization: Multiobjective genetic algorithm approach. New York, NY: Springer Science \& Business Media.

Gleason, N. W. (2018). Higher education in the era of the fourth industrial revolution. Singapore: Palgrave Macmillan.

Guerra, L. (2020, October 7). International Association of Universities: The global voice of higher education. Retrieved from https://www.iauaiu.net/UNESCO-IAU-Global-survey-on-the-role-of-HEIs-in-promoting-lifelong-learning (October 13, 2020).

Gültan, S. (2003). Bilgi tophımu sïrecinde Avrupa Birliği ve Türkiye. Ankara: Ankara Üniversitesi Basımevi.

Halili, S. H. (2019). Technological advancements in education 4.0. The Online Fournal of Distance Education and E-Learning, 7(1), 63-69.

Harkins, A. (2008). Leapfrog principles and practices: Core components of education 3.0 and 4.0. Futures Research Quarterly, 24(1), 19-31.

Haron, H. (2018). Education in the Era of IR 4.0. 2018 International Conference on Information Management and Technology (ICIMTech 2018) at Alam Sutera Main Campus, Bina Nusantara University, September 3-5, 2018, Jakarta, Indonesia. Retrieved from https://pdfs.semanticscholar.org/0fbc/eaf2915100318253ada2fc5213e7435311b9.pdf (October 17, 2020) 
Hermann, M., Pentek, T., \& Otto, B. (2016). Design principles for industrie 4.0 scenarios: A literature review. 49th Hawaii International Conference on System Sciences, (pp. 3928-3937), January 5-8, 2016, Koloa, HI, USA.

Hillage, J., \& Pollard, E. (1998). Employability: Developing a framework for policy analysis. London: Department for Education and Employment.

Himmetoğlu, B., Ayduğ, D., \& Bayrak, C. (2020). Education 4.0: Defining the teacher, the student, and the school manager aspects of the revolution. Turkish Online Fournal of Distance Education, 21(Special IssueIODL), 12-28.

Jamaludin, R., McKay, E., \& Ledger, S. (2019). Are we ready for Education 4.0 within ASEAN higher education institutions? Thriving for knowledge, industry and humanity in a dynamic higher education ecosystem? Fournal of Applied Research in Higher Education, 12(3), 1161-1173.

Kagermann, H., Lukas, W.-D., \& Wahlster, W. (2011). Industrie 4.0: mit dem Internet der Dinge auf dem Weg zur 4. industriellen Revolution. VDINachrichten, 13-2011, 2. Retrieved from https://www.dfki.de/fileadmin/user_upload/DFKI/Medien/News_Media/Presse/PresseHighlights/vdinach2011a13-ind4.0-Internet-Dinge.pdf (October 16, 2020).

Kahraman, F. (2019, Feb 6). Toplum 5.0 : Toplum için teknoloji. Harvard Business Review Tïrkiye. Retrieved from https://hbrturkiye.com/blog/toplum-5-0-toplum-icin-teknoloji (November 11, 2020).

Karacan Özdemir, N., \& Ayaz, A. (2020). Construction of career development services according to industry 4.0: Needs, priorities and requirement. [Article in Turkish] Yiiksekögretim ve Bilim Dergisi, 10(1), 96-102.

Keats, D., \& Schmidt, J. (2007). The genesis and emergence of education 3.0 in higher education and its potential for Africa. First Monday, 12(3), $3-29$.

Kravchenko, A., \& Kyzymenko, I. (2019). The forth industrial revolution: New paradigm of society development or posthumanist manifesto. Philosophy \& Cosmology (22), 120-128.

Lee, M., Yun, J. J., Pyka, A., Won, D., Kodama, F., Schiuma, G., Park, K. (2018). How to respond to the fourth industrial revolution, or the second information technology revolution? Dynamic new combinations between technology, market, and society through open innovation. fournal of Open Innovation: Technology, Market, and Complexity, 4(3), 21-45.

Lekha, E. A. (2019). Impact of industry 4.0 on higher education. Retrieved from https://lekha.info/2019/06/impact-of-industry-4-0-on-highereducation/ (October 12, 2020).

Li, L. (2020). Education supply chain in the era of Industry 4.0. System Research and Behavioral Science, 37(4), 579-592.

Liboni, L. B., Cezarino, L. O., Jabbour, C. J., Oliveira, B. G., \& Stefanelli, N. O. (2019). Smart industry and the pathways to HRM 4.0: Implications for SCM. Supply Chain Management, 24(1), 124-146.

Lodder, J. (2016, Şubat 21). The Fourth Industrial Revolution and the education system how to respond? Retrieved from https://www.linkedin.com/pulse/fourth-industrial-revolution-education-system-how-respond-john-lodder/ (October 11, 2020).

Man, J. C., \& Strandhagen, J. O. (2017). An Industry 4.0 research agenda for sustainable business models. Procedia CIRP, 721-726.

McQuaid, R. W., \& Lindsay, C. (2005). The concept of employability. Urban Studies, 42(2), 197-219.
Merrill, B., Finnegan, F., O’Neill, J., \& Revers, S. (2020). When it comes to what employers are looking for, I don't think I'm it for a lot of them: Class and capitals in, and after, higher education. Studies in Higher Education, 45(1), 163-175.

Mohajan, H. (2019a). The first industrial revolution: Creation of a new global human era. Fournal of Social Sciences and Humanities, 5(4), 377387.

Mohajan, H. (2019b). The second industrial revolution has brought modern social and economic developments. Fournal of Social Sciences and Humanities, 6(1), 1-14.

Mokyr, J. (1999). The second industrial revolution, 1870-1914. Rome: Laterza Publishing.

Morrar, R., Arman, H., \& Mousa, S. (2017). The Fourth Industrial Revolution (Industry 4.0): A social innovation perspective. Technology Innovation Management Review, 7(11), 12-20.

OECD (2008). 21st Century skills: How can you prepare students for the new global economy? Paris: Cisco Systems. Retrieved from https:// www.oecd.org/site/educeri21st/40756908.pdf (October 16, 2020).

OECD (2019). OECD employment outlook 2019. Retrieved from http://www.oecd.org/employment/outlook/ (May 1, 2019).

Özdemir, S. M. (2011). Education and curricula within the context of social change and globalization: A conceptual analysis. [Article in Turkish] Abi Evran Eğitim Fakiiltesi Dergisi, 12(1), 85-110.

Passow, H. J., \& Passow, C. H. (2017). What competencies should undergraduate engineering programs emphasize? A systematic review. Fournal of Engineering Education, 106(3), 475-526.

Peters, M. A. (2017). Technological unemployment: Educating for the fourth industrial revolution. Educational Philosophy and Theory, 49(1), $32-41$.

Puncreobutr, V. (2016). Education 4.0: New challenge of learning. St. Theresa fournal of Humanities, 2(2), 92-97.

Reich, R. (1992). The work of nations: Preparing ourselves for 21st century capitalism. New York, NY: Knopf Publishing.

Rojko, A. (2017). Industry 4.0 concept: Background and overview. International fournal of Interactive Mobile Technologies (ifIM), 11(5), $77-90$.

Sharma, P. B., \& Vij, S. (2020). Universities for the future jobs and human excellence. In P. Mittal, \& S. R. D. Pani (Eds.), Reimagining Indian universities (Essay No. 24), New Delhi: Association of Indian Universities.

Singh, R. (2020). Towards making Indian universities relevant and future ready. In P. Mittal, \& S. R. D. Pani (Eds.), Reimagining Indian universities (Essay No. 5), New Delhi: Association of Indian Universities.

Smith, B. L. (2001). The third industrial revolution: Policymaking for the Internet. Science and Technology Law Review, 3(1), 1-45.

Stauffer, B. (2020). What are 21st century skills? Retrieved from https://www.aeseducation.com/blog/what-are-21st-century-skills (October 16, 2020).

Stock, T., \& Seliger, G. (2016). Opportunities of sustainable manufacturing in industry 4.0. Procedia CIRP, 40, 536-541.

Stork, M. G. (2020). Supporting twenty-first century competencies using robots and digital storytelling. Fournal of Formative Design in Learning, $4,43-50$

THE (2017). Preparing for education 4.0. Retrieved from https://www. timeshighereducation.com/hub/jisc/p/preparing-education-40 (October 11, 2020). 
Tonta, Y., \& Küçük, M. E. (2005). Main dynamics of the transition from industrial society to information society. [Article in Turkish] Tiirk Kiitiiphaneciliği, 19(4), 449-464.

Troxler, P. (2013). Making the 3rd industrial revolution. The struggle for polycentric structures and a new peer production. Bielefeld: Transcript Publishers.

UNESCO (2020). International research project: The contribution of higher education institutions to lifelong learning. Retrieved from UNESCO Institute for Lifelong Learning: https://uil.unesco.org/lifelong-learning/higher-education-lifelong-learning (October 12, 2020).

University of the Future (2018). University of the future. Industry 4.0: Implications for higher education Institutions. European Commission. Retrieved from www.universitiesofthefuture.eu (November 10, 2020).

University of the Future (2020). The virtual teaching and learning factory for Industry 4.0 is ready to use! Retrieved from https://universitiesofthefuture.eu/: https://universitiesofthefuture.eu/blog/2020/09/24/1399/ (October 14, 2020).

US Government (2016). Artificial intelligence, automation, and the economy. Washington, DC: Executive Office of the President. Retrieved from https://obamawhitehouse.archives.gov/sites/whitehouse.gov/files/documents/Artificial-Intelligence-Automation-Economy.pdf (October 12, 2020).
WEF (2016). The Fourth Industrial Revolution: What it means, how to respond. World Economic Forum. Retrieved from https://www.weforum.org/agenda/2016/01/the-fourth-industrial-revolution-what-itmeans-and-how-to-respond (October 18, 2020).

WEF (2018). WEF. The future of jobs report. Geneva: World Economic Forum. Retrieved from http://www3.weforum.org/docs/WEF_Future_of_Jobs_2018.pdf (October 18, 2020).

WEF (2020). Fobs of tomorrow mapping opportunity in the new economy. Geneva: World Economic Forum. Retrieved from http://www3.weforum.org/docs/WEF_Jobs_of_Tomorrow_2020.pdf (October 12, 2020).

Xing, B., \& Marwala, T. (2017). Implications of the fourth industrial age on higher education. Retrieved from https://arxiv.org/abs/1703.09643.pdf (October 12, 2020).

Yang, J., Schneller, C., \& Roche, S. (2015). The role of higher education in promoting lifelong learning. Hamburg: UNESCO Institute for Lifelong Learning.

Yazıc1, E., \& Düzkaya, H. (2016). Four waves in industrial revolution and education: Is Turkey ready for four waves in industrial revolution? [Article in Turkish] Fournal of Education and Humanities: Theory and Practice, 7(13), 49-88.

Yıldız, A. H. (2017). Üniversite 4.0'a geçiş süreci: Kavramsal bir yaklaşım. Açıköğretim Uygulamaları ve Araştırmalan Dergisi, 3(2), 164-176.

Bu makale Creative Commons Attribution-NonCommercial-NoDerivs 4.0 Unported (CC BY-NC-ND 4.0) Lisansı standartlarında; kaynak olarak gösterilmesi koşuluyla, ticari kullanım amacı ve içerik değişikliği dışında kalan tüm kullanım (çevrimiçi bağlantı verme, kopyalama, baskı alma, herhangi bir fiziksel ortamda çoğaltma ve dağıtma vb.) haklarılla açık erişim olarak yayımlanmaktadır. / This is an open access article distributed under the terms of the Creative Commons AttributionNonCommercial-NoDerivs 4.0 Unported (CC BY-NC-ND 4.0) License, which permits non-commercial reuse, distribution and reproduction in any medium, without any changing, provided the original work is properly cited.

Yayıncı Notu: Yayıncı kurulus olarak Deomed bu makalede ortaya konan görüslere katılmak zorunda değildir; olası ticari ürün, marka ya da kuruluslarla ilgili ifadelerin içerikte bulunmas yayıncının onayladığı ve güvence verdiği anlamına gelmez. Yayının bilimsel ve yasal sorumlulukları yazar(lar)ına aittir. Deomed, yayınlanan haritalar ve yazarların kurumsal bağlantıları ile ilgili yarg1 yetkisine ilişkin iddialar konusunda tarafsızdır. / Publisher's Note: The content of this publication does not necessarily reflect the views or policies of the publisher, nor does any mention of trade names, commercial products, or organizations imply endorsement by Deomed. Scientific and legal responsibilities of published manuscript belong to their author(s). Deomed remains neutral with regard to jurisdictional claims in published maps and institutional affiliations. 